experiments in New York, Paris and other places. It will be evident from this very brief account of his work that Prof. Hahn's contributions to radioactivity have been of outstanding importance. $\mathrm{He}$ has also taken a prominent part, with his students and colleagues, in developing methods of studying chemical problems by the use of radioactive indicators.

\section{Dr. C. D. Darlington}

DR. C. D. DarLington has been appointed to succeed Sir Daniel Hall as director of the John Innes Horticultural Institution, Merton. Dr. Darlington was educated at St. Paul's School, Hammersmith, where he was a Foundation Scholar, and the SouthEastern Agricultural College, Wye. He went to the John Innes Horticultural Institution in 1923, in Dr. Bateson's time. Here his interest was attracted to chromosome studies by the late W. C. F. Newton. As the importance of this kind of work in relation to breeding became recognized, it was considerably extended at the John Innes Institution, and in 1937 Dr. Darlington was appointed head of the Cytology Department. In 1929, he travelled to Persia and Transcaucasia to investigate the origin of cultivated forms of Prunus and Tulipa. During 1932-33, he worked in the United States for eight months as a Rockefeller Foundation Scholar, visiting Japan and India on his way home. In the winter of 1937-38, he was a delegate to the Indian Science Congress jubilee meeting. He is at the present time acting as recorder to the Cytology Section of the International Genetical Congress. Dr. Darlington, who is well known for his work in the field of genetics and cytology, has published "Chromosomes and Plant Breeding" (1932), "Recent Advances in Cytology" (1932; second edition 1937), "The Evolution of Genetic Systems" (1939), together with numerous scientific communications. $\mathrm{He}$ is a collaborating editor of the new journal Chromosoma (see p. 372 of this issue). The appointment takes effect from October 1, 1939.

\section{Mr. James Henderson}

THE Iron and Steel Institute has awarded the Bessemer Gold Medal to Mr. James Henderson. The Bessemer Medal was founded by Sir Henry Bessemer, and is awarded annually for distinguished merit in promoting the-technical and metallurgical development of the iron and steel industry; it is the highest honour which the Institute can give. Mr. Henderson was associated for forty-five years with the technical development of the Frodingham Iron and Steel Co., Ltd., in North Lincolnshire and held all positions from chief metallurgist to managing director. During that period, the works became one of the most important in the country, and were associated with such important developments as the introduction of the Talbot direct metal process, the use of blast-furnace gas in blowing and power engines, and the installation of modern plate mills. Mr. Henderson is now deputy chairman of the renamed Appleby-Frodingham Steel Co., Ltd., and a director of the United Steel Companies, Ltd.; he is past-president of the British Iron and Steel Federation and of the Lincolnshire Iron and Steel
Institute. $\mathrm{He}$ is one of the only two Englishmen whose services to the industry have been recognized by nomination to honorary membership of the Verein deutscher Eisenhüttenleute.

\section{Ludwig Mond, F.R.S. (1839-1909)}

Ludwig Mond, patron of the arts and sciences, was born on March 7, 1839, and the commemoration of his centenary is a convenient opportunity to recall something of what we owe to him. Originally German and later a naturalized British subject, he perfected and established in Great Britain the ammonia-soda process which brought into being the firm of Messrs. Brunner, Mond and Company, the nucleus of Messrs. Imperial Chemical Industries, Limited. $\mathrm{H}_{\Theta}$ also devised satisfactory processes of nitrogen recovery and for the manufacture of producer gas, which latter process is the property of the Power Gas Corporation. No less well known is Ludwig Mond's process for the production of pure nickel, in which a newly discovered and unique compound immediately found important technical application. Throughout his life, he was pre-eminent as a chemist and investigator. His amassing great wealth was the result and not the object of his work.

Some of Ludwig Mond's public benefactions for the encouragement of scientific investigation may be recalled. During his life he gave $£ 100,000$ for the founding and endowment of the Davy Faraday Laboratory of the Royal Institution, and $£ 16,000$ for the continuance and improvement of the catalogue of scientific papers of the Royal Society. He bequeathed $£ 50,000$ to the Royal Society "for the endowment of research in Natural Science more particularly but not exclusively in Chemistry and Physics". He also bequeathed a similar sum to the University of Heidelberg and $£ 25,000$ to Cassel, his native town in Germany. He gave to the nation, together with an endowment for its maintenance, the Mond Collection, chiefly of early Italian paintings, now well known as an important part of the National Gallery. This, and his bequest of $£ 20,000$ to the Münich Akademie der bildenden Künste, are memorials to Ludwig Mond's own appreciation of art and to the care he took that others should benefit by it. Truly, this was a great man.

\section{Frederick Howard Marsh (1839-1915)}

Howard MARSH, an eminent London surgeon and master of Downing College, Cambridge, was born on March 7, 1839, at Homersfield, near Bungay, Suffolk, the son of a gentleman farmer. He received his medical education at St. Bartholomew's Hospital, where he was a contemporary of Alfred Willett (see NAture, 139, $61 ; 1937$ ) and qualified L.S.A. and M.R.C.S. in 1861. Five years later he became F.R.C.S. and was appointed surgeon to the Queen Square House of Relief for Children with Chronic Disease of the Joints. In 1868, he was elected assistant surgeon to the Great Ormond Street Hospital for Sick Children, where he afterwards became full surgeon and consulting surgeon. Between 1865 and 